\title{
Chemical composition and dry matter digestibility of sugar cane oxide treated with calcium
}

\author{
[Composição química e digestibilidade da matéria seca da cana-de-açúcar \\ tratada com óxido de cálcio] \\ C.O. Romão ${ }^{1}$, G.G.P. Carvalho ${ }^{2}$, V.M. Leite $^{2}$, A.S. Santos ${ }^{3}$, D.M.T. Chagas $^{4}$, \\ O.L. Ribeiro ${ }^{2}$, P.A. Oliveira ${ }^{5}$, A.F. Magalhães ${ }^{6}$, A.J.V. Pires ${ }^{7}$ \\ ${ }^{1}$ Aluno de pós-graduação - Universidade Federal da Bahia - UFBA - Salvador, BA \\ ${ }^{2}$ Universidade Federal da Bahia - UFBA - Salvador, BA \\ ${ }^{3}$ Aluna de graduação - Universidade Federal da Bahia - UFBA - Salvador, BA \\ ${ }^{4}$ Programa de pós-graduação - Universidade Estadual do Sudoeste da Bahia - Itapetinga, BA \\ ${ }^{5}$ Programa de pós-graduação - Universidade Federal do Recôncavo da Bahia - Cruz das Almas, BA \\ ${ }^{6}$ CEPLAC - Ilhéus, BA. \\ ${ }^{7}$ Universidade Estadual do Sudoeste da Bahia - Itapetinga, BA
}

\begin{abstract}
The aim of this study was to identify the most adequate level of calcium oxide $(\mathrm{CaO})$ in the treatment of sugar cane by evaluating the chemical composition and in vitro digestibility of dry matter. The sugar cane was homogenized with $\mathrm{CaO}$ levels $0,0.75,1.5,2.25,3.0,3.75$ and $4.5 \%$, in natura matter, for 24 hours. The dry matter and mineral matter increased, while the organic matter of the sugar cane decreased $(\mathrm{P}$ $<0.05$ ) linearly as a result of the $\mathrm{CaO}$ levels. The $\mathrm{CaO}$ had no effect on the levels of crude protein and ether extract. The phosphorus concentration remained unchanged, but there was a significant increase $(\mathrm{P}<0.05)$ in the calcium content. The contents of neutral detergent fiber, acid detergent fiber and cellulose decreased linearly with the levels of $\mathrm{CaO}$. The average levels of indigestible dry matter and indigestible neutral detergent fiber significantly decreased with increasing levels of $\mathrm{CaO}$. The results showed that the in vitro dry matter digestibility (IVDMD) was different between fresh sugar cane and sugar cane with added levels of $\mathrm{CaO}$ from $1.5 \%$. The IVDMD and nutritional value of the sugar cane was improved by adding $1.5 \% \mathrm{CaO}$ based on fresh content.
\end{abstract}

Keywords: additive, forage, hydrolysis, Saccharum, alkaline treatment

\section{RESUMO}

O objetivo foi identificar o nível mais adequado de óxido de cálcio (CaO) no tratamento da cana-deaçúcar por meio da avaliação da composição química e a digestibilidade in vitro da matéria seca. A cana-de-açúcar foi homogeneizada adicionando os níveis de $\mathrm{CaO}$ 0; 0,75; 1,5; 2,25; 3,0; 3,75 e 4,5\% em porcentagem de matéria natural, por 24 horas. Os teores de matéria seca e matéria mineral aumentaram, ao passo que o teor de matéria orgânica da cana-de-açúcar diminuiu $(P<0,05)$ de forma linear em função dos níveis de CaO. Não houve efeito dos níveis do CaO sobre o teor de proteína bruta e extrato etéreo. Os teores médios de fósforo mantiveram-se inalterados, porém ocorreu um aumento $(P<0,05)$ no teor de cálcio. Os teores de fibra em detergente neutro, fibra em detergente ácido e celulose diminuíram linearmente em função dos níveis de CaO. Os teores médios da matéria seca indigestível e da fibra em detergente neutro indigestível tiveram redução significativa com o aumento dos níveis de CaO. Os resultados da digestibilidade in vitro da matéria seca (DIVDM) mostraram-se diferentes entre cana-deaçúcar in natura e a com níveis de CaO. Níveis de CaO a partir de 1,5\% melhoram o valor nutritivo e a DIVDM da cana-de-açúcar.

Palavras-chave: aditivo, forragem, hidrólise, Saccharum, tratamento alcalino

Recebido em 6 de julho de 2012

Aceito em 16 de outubro de 2013

E-mail: cromao@email.it

Apoio financeiro: FAPESB 


\section{INTRODUCTION}

The use of sugar cane (Saccharum officinarum L.) is known by small farmers for its importance between traditional forage harvests. The advantages are many, such as the speed of the shoots, the tillering and the early growth of stems (Abranches and Bolonhezi, 2011), but the main advantage is the high productivity of green mass that stands up to $145 \mathrm{t} /$ ha per year (Barbosa and Silveira, 2006). As a forage resource for ruminants, it is considered one of the alternatives used for minimizing the inadequate nutrition of animals, especially in drought periods (Freitas, 2008), which coincide with the off-season production of tropical pastures (Oliveira et al., 2002), favoring its use as forage for ruminants in the dry season.

Regarding its nutritional quality, this forage is considered a high-energy food, with an elevated carbohydrate ratio, but also high levels of indigestible fiber and low amounts of protein. It is considered an unbalanced food (Sobreira, 2006) in its composition, with high lignin content, a cell wall element that negatively influences the digestibility of fiber, causing lower levels of animal productivity. The fiber fraction of sugar cane limits the nutritional intake due to a cell wall structure that prevents microbial digestion in the rumen.

One alternative that has been studied is the use of chemical additives in the treatment as a viable option for improving the nutritional value of different forages. These studies aimed to improve animal production efficiency and reduce the damage caused by the ingestion of portions of non-digestible or non-degradable fiber, and to evaluate the contribution of additives in nutritional quality, digestibility and aerobic stability of both ensiled and fresh forage
(Balieiro Neto et al., 2007, Carvalho et al., 2009; Cavali et al., 2010, Mota et al., 2010).

Recently, the use of calcium oxide $(\mathrm{CaO})$ in the treatment of sugar cane has been reported to maintain the nutritional quality of forage for a few days without the need for daily cuts (Oliveira et al., 2007) and to improve its nutritional value (Pires et al., 2010; Carvalho et al., 2013).

Thus, this study has been conducted to identify the most appropriate level of calcium oxide in the treatment of sugar cane by evaluating the chemical composition and in vitro digestibility of dry matter.

\section{MATERIAL AND METHODS}

The sugar cane used was of the RB 86-2480 variety, produced at the Experimental Farm of Santa Maria in the Federal University of Bahia (UFBA), where the experiment was initiated. The experimental design was conducted in March 2010 and the analysis in April and November of that year.

The sugar cane was harvested manually, by removing the straw then disintegrating and separating the basic material (in natura sugar cane). Heaps of $3 \mathrm{~kg}$ were made and homogenized in proportion to the levels of $\mathrm{CaO}$ powder, $0,0.75,1.5,2.25,3.0,3.75$ and $4.5 \%$ of DM of natural material, arranged in 28 piles, which remained at room temperature for 24 hrs after application. During this period, temperatures were measured every 6 hours within the piles (Table 1). The sugar cane at zero calcium oxide did not suffer any dilution, and remained at room temperature during the entire $24 \mathrm{~h}$.

Table 1. Temperature values obtained in the sugar cane piles treated with calcium oxide $(\mathrm{CaO})$ measured at different times after the treatment

\begin{tabular}{cccccc}
\hline \multirow{2}{*}{ Calcium oxide levels (\% MN) $)$} & \multicolumn{5}{c}{ Times (h) } \\
\cline { 2 - 6 } & 0 & 6 & 12 & 18 & 24 \\
\hline & & & Temperature ${ }^{\circ} \mathrm{C}$ & 42.8 & 44.3 \\
0.00 & 32.7 & 33.0 & 42.5 & 38.3 & 41.5 \\
1.50 & 33.0 & 35.3 & 37.0 & 31.6 & 31.8 \\
2.25 & 37.8 & 38.0 & 33.0 & 31.8 & 30.0 \\
3.00 & 44.3 & 42.9 & 35.1 & 31.6 & 30.4 \\
3.75 & 51.6 & 48.9 & 36.5 & 31.5 & 30.0 \\
4.50 & 54.0 & 46.5 & 37.5 & 32.3 & 30.9 \\
\hline
\end{tabular}

Minimum and maximum temperature on assessment day $\left(24^{\circ} \mathrm{C}\right.$ and $29^{\circ} \mathrm{C}$, respectively). 
The experiment was analyzed according to a completely randomized design with eight processes (the material and sugar cane with $\mathrm{CaO}$ levels) and four repetitions.

The samples taken from the piles were immediately frozen in a refrigerator for further analysis. They were thawed and pre-dried in forced air $\left(55^{\circ} \mathrm{C}\right)$ for $72 \mathrm{hrs}$, then ground in a $1 \mathrm{~mm}$ sieve knife mill and packed into plastic bags, labeled and stored in a cool place for further chemical analysis. In the Animal Nutrition laboratories of the Federal University of Bahia and the Forage and Pasture laboratories of the State University of Southwest Bahia we stored the dry matter (DM), Ash, organic matter $(\mathrm{OM})$, crude protein $(\mathrm{CP})$, and ether extract (EE). The analysis of neutral detergent fiber (NDF), hemicellulose, cellulose and lignin was conducted as described by Mertens (2002). Acid detergent fiber (ADF) was proceeded according to Van Soest (1991). In vitro digestibility of dry matter (IVDM) was evaluated according to procedures described by Tilley and Terry (1963).

The total carbohydrates (TC) and non-fibrous carbohydrates (NFC) were estimated by Sniffen et al. (1992) as: $\mathrm{TC}=100-(\% \mathrm{CP}+\% \mathrm{EE}+\%$ ash $)$ and $\mathrm{CNF}=(100-\% \mathrm{NDF}-\% \mathrm{CP}-\mathrm{EE} \%-\%$ ash).

To estimate the levels of indigestible dry matter (iDM) and indigestible neutral detergent fiber (iNDF), duplicate $\left(20 \mathrm{mg} \mathrm{DM} / \mathrm{cm}^{2}\right)$ samples of sugar cane were incubated for 240 hrs (Casali et al., 2008) in non-woven fabric bags (TNT $100 \mathrm{~g} / \mathrm{m}^{2}$ ) in the rumen of two crossbred steers kept on Brachiaria decumbens pasture. After this period the bags were removed, rinsed in tap water and brought to a forced air oven at $60^{\circ} \mathrm{C}$ for $72 \mathrm{~h}$. Following this stage, they were removed from the oven, placed in desiccators and weighed, and the obtained residue was considered iDM. In the residue obtained after this phase, we carried out the analysis of NDF according to the procedures described by Silva and Queiroz (2002). The analysis of calcium and phosphorus was performed in the Plant Tissue Analysis laboratory of the Executive Planning Cocoa Crop (CEPLAC). The phosphorus was obtained by colorimetry according to Fiske and Subbarow (1925) and calcium (Ca) by an atomic absorption spectrophotometer (Fick et al., 1979).

The effects of $\mathrm{CaO}$ levels were interpreted by analysis of variance and regression at 5\% probability and the comparison between the levels of $\mathrm{CaO}$ and in natura sugar cane was performed according to Dunnett (1955).

\section{RESULTS AND DISCUSSION}

The average DM content of in natura sugar cane (control) was $363.0 \mathrm{~g} / \mathrm{kg}$, significantly higher $(\mathrm{P}<0.05)$ than the values of 336.0 and $343.0 \mathrm{~g} / \mathrm{kg}$ observed, respectively, for sugar cane without additives and with addition of $0.75 \% \mathrm{CaO}$ (Table 2 ). These lower DM values are possibly related to the accumulation of water produced by fermentation of the treated material with little $\mathrm{CaO}$, given the high temperature (Table 1) for sugar cane without additive and with $0.75 \%$ of $\mathrm{CaO}$ at end of the treatment period.

Table 2. Average contents of dry matter (DM), ash, organic matter (OM), crude protein (CP), ether extract (EE), phosphorus $(\mathrm{P})$ and calcium $(\mathrm{Ca})$ of sugar cane in natura and treated with calcium oxide

\begin{tabular}{|c|c|c|c|c|c|c|c|c|c|}
\hline \multirow{2}{*}{$\begin{array}{l}\text { Variables } \\
(\mathrm{g} / \mathrm{kg})\end{array}$} & \multirow{2}{*}{$\begin{array}{l}\text { In Natura } \\
\text { Sugar Cane }\end{array}$} & \multicolumn{7}{|c|}{ Calcium oxide levels (\% MN) } & \multirow{2}{*}{$\begin{array}{l}\text { CV } \\
(\%)\end{array}$} \\
\hline & & 0 & 0.75 & 1.5 & 2.25 & 3.0 & 3.75 & 4.5 & \\
\hline $\mathrm{DM}$ & 363.0 & $336.0^{*}$ & $343.0 *$ & 355.0 & 372.0 & $390.0^{*}$ & $411.0^{*}$ & $416.0^{*}$ & 2.8 \\
\hline Ash & 27.0 & 40.0 & 45.0 & $70.0 *$ & $90.0 *$ & $88.0^{*}$ & $130.0^{*}$ & $142.0^{*}$ & 17.7 \\
\hline $\mathrm{OM}$ & 973.0 & 960.0 & 955.0 & $930.0 *$ & $910.0 *$ & $912.0 *$ & $870.0 *$ & $858.0^{*}$ & 1.5 \\
\hline $\mathrm{CP}$ & 18.0 & 21.0 & 20.0 & 20.0 & 20.0 & 20.0 & 19.0 & 19.0 & 14.0 \\
\hline $\mathrm{EE}$ & 4.0 & 5.0 & 4.0 & 4.0 & 4.0 & 3.0 & 3.0 & 3.0 & 20.0 \\
\hline $\mathrm{P}$ & 0.3 & 0.3 & 0.3 & 0.3 & 0.3 & 0.3 & 0.3 & 0.4 & 11.3 \\
\hline $\mathrm{Ca}$ & 2.3 & 14.0 & $17.2 *$ & $35.9 *$ & $50.5^{*}$ & $57.0 *$ & $69.2 *$ & $78.5^{*}$ & 10.7 \\
\hline
\end{tabular}

* Means followed by an asterisk differ from in natura sugar cane (control) at 5\% probability by Dunnett's test. CV $=$ coefficient of variation in $\%, \mathrm{MN}=$ natural matter. ${ }^{1}(\% \mathrm{DM})$. 
Among the tested levels of $\mathrm{CaO}$, the $3.0,3.75$ and $4.5 \%$ had higher $\mathrm{DM}$ rates $(\mathrm{P}<0.05)$, respectively: $390.0,411.0$, and $416.0 \mathrm{~g} / \mathrm{kg}$, when compared to sugar cane without the addition of $\mathrm{CaO}$ (in natura sugar cane). The DM content of
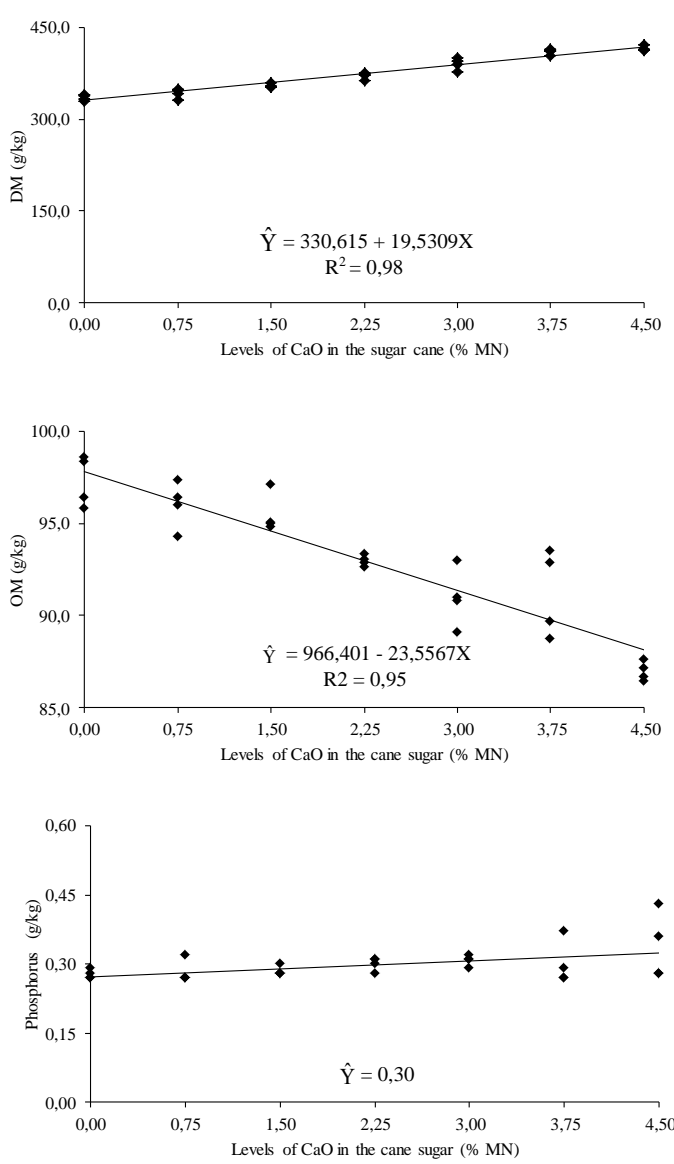

sugar cane increased $(\mathrm{P}<0.05)$ linearly due to the $\mathrm{CaO}$ levels (Fig. 1). This increase $(\mathrm{P}<0.05)$ may be due to the high DM content of the additive, causing an additive effect.
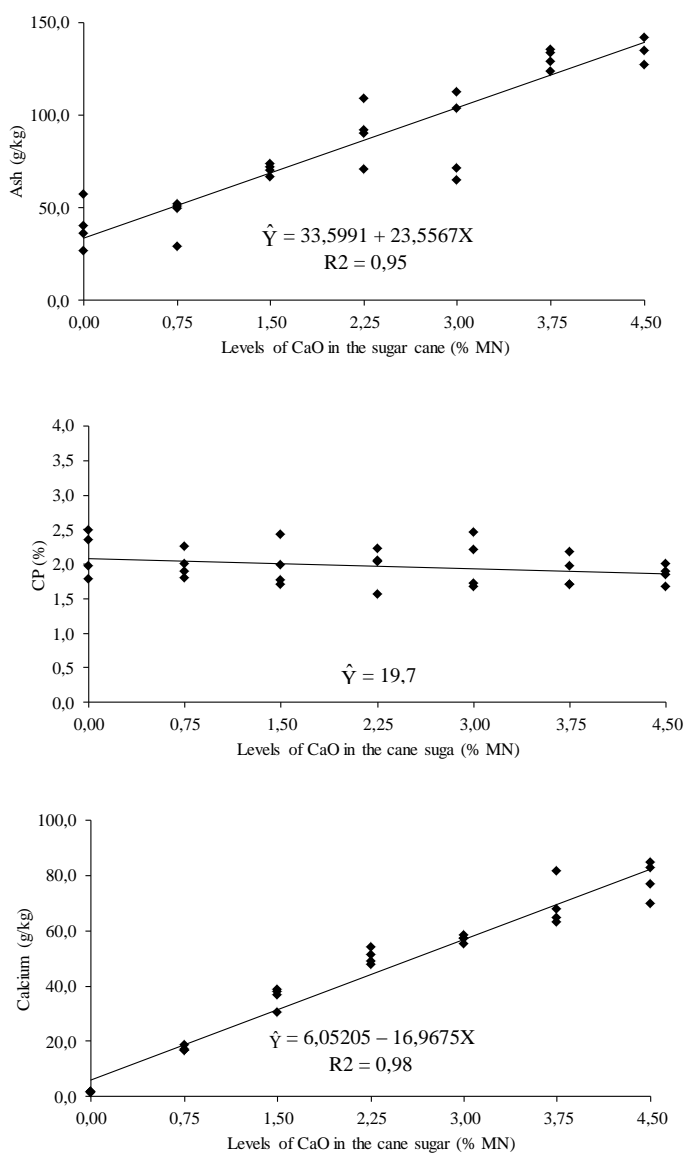

Figure 1. Dry matter (DM), ash, organic matter (OM), crude protein (CP), phosphorus and calcium from sugar cane treated with different levels of calcium oxide $(\mathrm{CaO})$ as a percentage of natural matter $(\mathrm{NM})$

The storing of forage in a ventilated environment, subject to constant dehydration, can also help raise the DM level. In this study, sugar cane was exposed in an open shed for 24 hrs, which may also have contributed to the increase in DM content. This same condition was reported by Carvalho et al. (2009) in assessing the chemical composition and dry matter digestibility of sugar cane bagasse treated with $\mathrm{CaO}$ at levels of $0,1.25,2.5$ and $3.75 \%$.

After the addition of $1.5 \% \mathrm{CaO}$ in sugar cane differences were observed in the concentration of ash and $\mathrm{OM}$ in relation to that of fresh sugar cane (control) (Table 1). For both the ash and for the OM, a linear effect was noticed, the ash increasing and the OM levels decreasing (Fig. 1). This behavior is related to the composition of $\mathrm{CaO}$, i.e., high levels of minerals, due to the addition of $\mathrm{CaO}$ used in the hydrolysis, which leads to an increase in the ash and decrease in the levels of the OM in linearly treated material due to the greater amount of lime applied to the sugar cane. This also explains the higher values of ash in the cane with $\mathrm{CaO}$ levels in relation to in natura sugar cane (control). Oliveira et al. (2008) also found reduced and increased content of DM and ash, respectively, when hydrated lime was added. Ribeiro et al. (2009a) studied the nutritive value of sugar cane hydrolyzed with sodium hydroxide or calcium oxide and between these two additives, in high calcium 
concentration, $\mathrm{CaO}$ caused increase in the sugar cane ash when compared to $\mathrm{NaOH}$.There was no effect $(\mathrm{P}>0.05)$ of $\mathrm{CaO}$ on crude protein $(\mathrm{CP})$ of sugar cane (Table 1), since the average value was $19.7 \mathrm{~g} / \mathrm{kg} \mathrm{CP}$ level regardless of the additive. This result can be explained by the absence of elements that contribute to the increase of $\mathrm{CP}$ in this additive. Azevedo et al. (2003), when working with three varieties of sugar cane, one in its early stages (SP 80-1842) and two at intermediate cycles of maturity (RB 84-5257 and SP 79-1011), highlighted the low contribution of sugar cane $\mathrm{CP}$ in feed formulation based on this forage. The results of this study agree with those obtained by Ribeiro et al. (2009b) who found no effect of $\mathrm{CaO}$ and sodium hydroxide on the crude protein content of sugar cane.

On the other hand, Carvalho et al. (2006) noticed an elevation of $\mathrm{CP}$ in experiments adding urea to sugar cane. The urea or anhydrous ammonia is widely used because it has the power to correct the crude protein content of sugar cane by increasing non-protein nitrogen. The $\mathrm{CP}$ was not affected by the addition of $\mathrm{CaO}$ levels in sugar cane (Figure 1) and the explanation is the absence of protein components in its composition.

For EE (Table 1), the results were close and there was no difference $(\mathrm{P}<0.05)$ between the sugar cane treated with levels of $\mathrm{CaO}$ and in natura sugar cane (control). Similarly, the EE content was unaffected $(\mathrm{P}>0.05)$ by $\mathrm{CaO}$ in sugar cane, verifying the average value of 3.7. The lack of any significant effect on the EE content in sugar cane caused by the levels of $\mathrm{CaO}$ can be explained by the lack of this component in the additive, which did not have any contribution to the EE content in the material changed.

There was no difference in the average levels of phosphorus $(\mathrm{P}>0.05)$ with the addition of different levels of $\mathrm{CaO}$, but the calcium content increased $(\mathrm{P}<0.05)$ in levels of $0.75,1.5,2.25$, $3.0,3.75$ and $4.5 \%$ at concentrations of 172.0 , $359.0, \quad 505.0, \quad 570.0, \quad 692.0$ and $785.0 \mathrm{~g} / \mathrm{kg}$, respectively (Table 2). This change in the calcium:phosphorus ratio in sugar cane was quite significant, with values of, respectively, 3.0 and $23.0 \mathrm{~g} / \mathrm{kg}$ (in natura sugar cane) to 4.0 and $785.0 \mathrm{~g} / \mathrm{kg}$ (for sugar cane with $4.5 \%$ ) of phosphorus and calcium, an increase of $3413.1 \%$ in the calcium content. Mota et al. (2010) found an average increase in calcium 605.88 and $452.94 \%$, respectively, for sugar cane hydrolyzed with quicklime and hydrated lime, both at $0.5 \%$ for each treatment regarding in natura sugar cane. The highest values obtained in this study are listed for lower levels of $\mathrm{CaO}$ used, tested by Mota et al. (2010), who used $0.5 \%$ for each treatment.

Excess calcium can promote a zinc deficiency and may bring parakeratosis in cattle (Tokarnia et al., 2000). Excess calcium in silage with quicklime can be harmful to animals, especially if the food associated with elevated levels of this mineral, such as citrus pulp (Schmidt et al., 2010). Excessive intake of calcium should be avoided due to the strong antagonism between calcium and zinc and the risk of deficiency of the latter, except for cases of cattle demineralization. Especially in calcium, hydrolyzed sugar cane with $\mathrm{CaO}$ may have a beneficial effect due to greater amounts of $\mathrm{Ca}$. The phosphorus content in the sugar cane was not affected by the addition of $\mathrm{CaO}(\mathrm{P}>0.05)$, while the calcium content increased linearly (Figure 1). The increase $(\mathrm{P}<0.05)$ is attributed to the high concentration of this essential chemical element in the composition of $\mathrm{CaO}$.

The contents of neutral detergent fiber (NDF), acid detergent fiber (ADF) and cellulose brought about the increase of $\mathrm{CaO}$ levels in sugar cane (Table 2). The quantities of this element decreased linearly $(\mathrm{P}<0.05)$ in the content of these components as the levels of the additive increased (Figure 2), which can be explained by alkaline hydrolysis and solubilization of cell wall components of sugar cane, as well as the probable dilution effect. This same result was found by Carvalho et al. (2009) and Cavalli et al. (2010) who observed a reduction in NDF, ADF and cellulose respectively, crushed sugar cane treated with $0,1.25,2.5$ and $3.75 \%$ in two treatment periods, 12 and $36 \mathrm{~h}$, with $\mathrm{CaO}$, and the silage sugar cane treated with $0,0.5,1.0,1.5$ and $2.0 \%$.

The lower values for NDF, ADF and cellulose in sugar cane treated chemically in this study (Table 3) is consistent with the results reported previously by Ribeiro et al. (2009a) who assessed the nutritive value and aerobic stability in the temperature of hydrolyzed sugar cane with 
sodium hydroxide $(\mathrm{NaOH})$ or $\mathrm{CaO}$ and detected quantities of the effect on the levels of neutral detergent fiber (NDF) acid detergent fiber (ADF) and cellulose, which showed linear decrease with increasing levels of $\mathrm{NaOH}$ and $\mathrm{CaO}$, and the most significant reductions were observed with the maximum level $(2.25 \%)$. The present results are also consistent with those of Balieiro Neto et al. (2007) who studied the effects of $\mathrm{CaO}$ at the time of ensiling and post-opening levels of 0.5 , 1.0 and $2.0 \%$ in sugar cane silages and found the
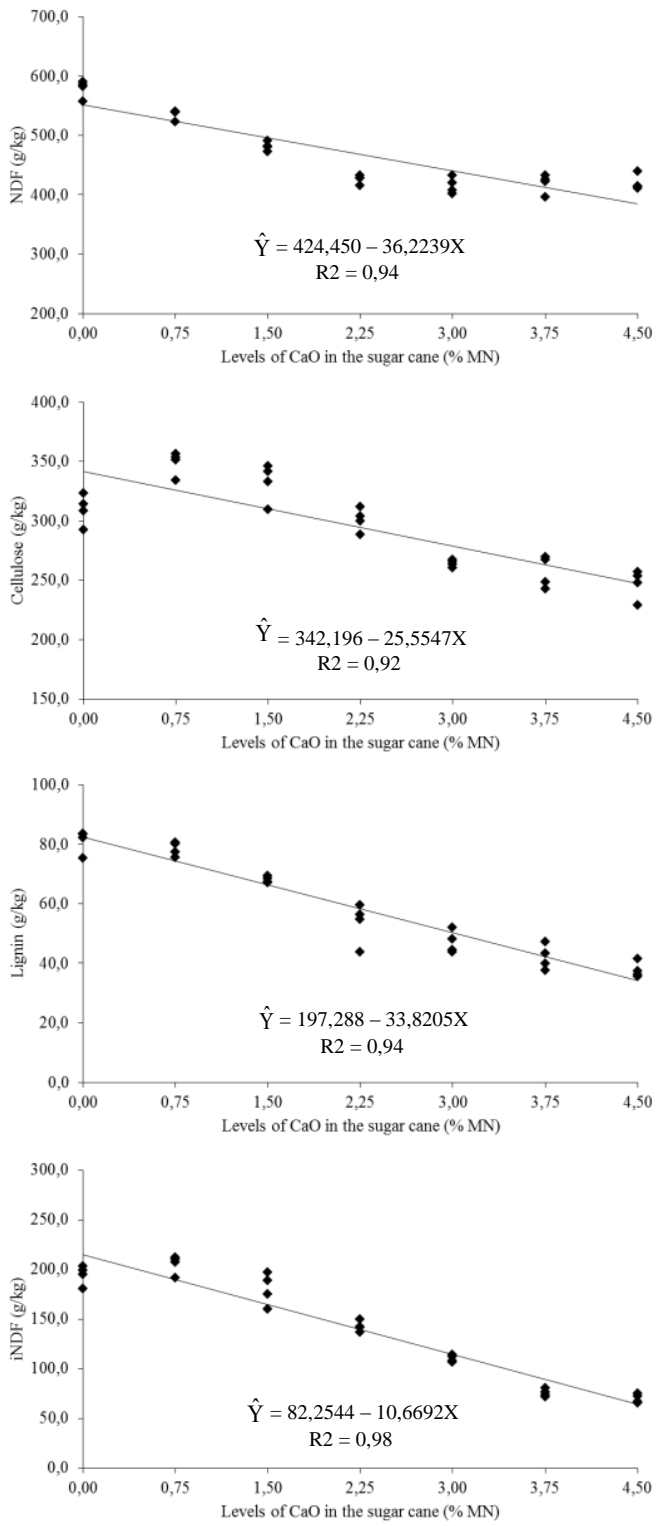

NDF and ADF of silages higher than the control with the silage additive at all times, and further with $2.0 \%$ silage additive levels were lower than those with 0.5 and $1.0 \%$ additive at all times. All this points to these reductions being brought about after the use of the additive, connected to the disruption of lignocellulosic structures, resulting from the alkaline hydrolysis, once the pulp is liable to be hydrolysed hexoses, pentoses and the hemicellulose.
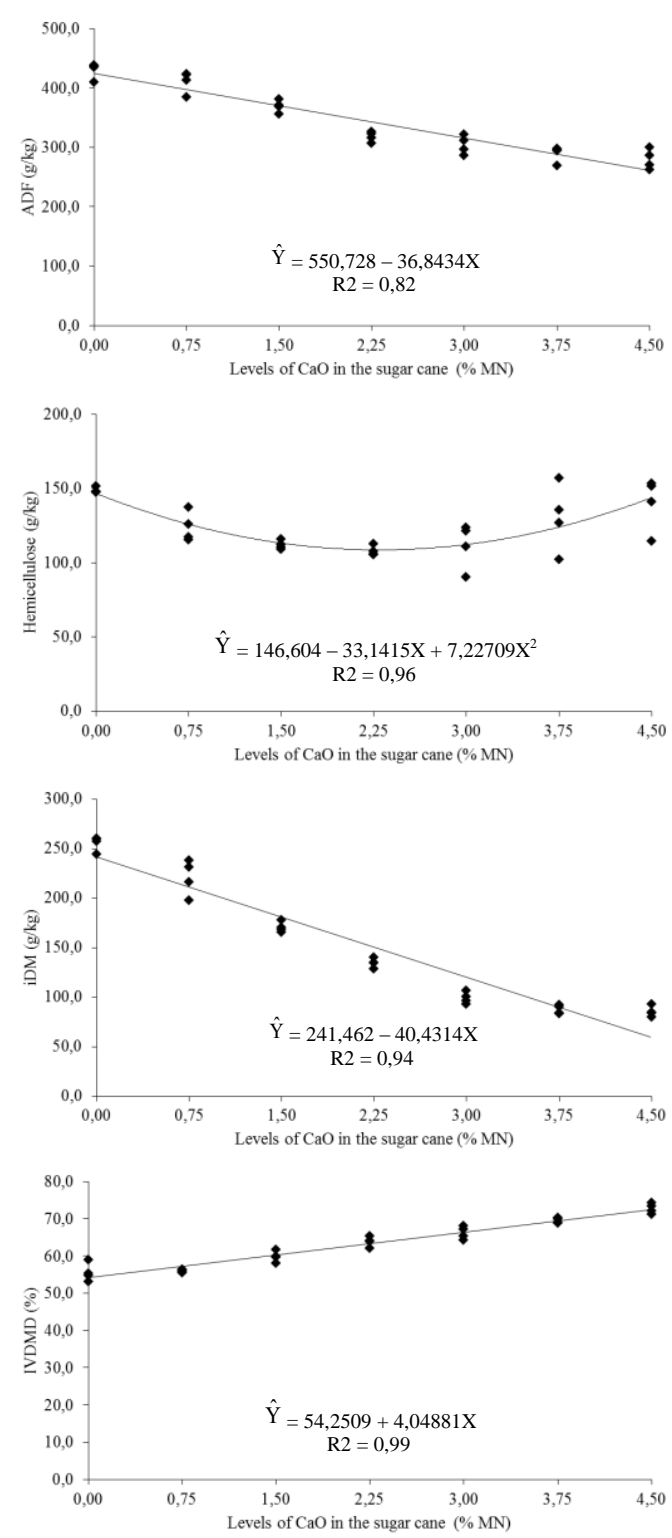

Figure 2. Neutral detergent fiber (NDF), acid detergent fiber (ADF), cellulose, hemicellulose, lignin, indigestible dry matter (iDM), indigestible neutral detergen fiber (iNDF) and in vitro digestibility of dry matter (IVDMD) contents in sugar cane treated with different levels of calcium oxide $(\mathrm{CaO})$ in percentage of the natural matter (NM). 
The levels of $\mathrm{CaO}$ had a significant effect $(\mathrm{P}<0.05)$ on the hemicellulose content of the sugar cane (Table 3 ). There were higher levels of hemicelluloses in the sugar cane treated with 0 and $4.5 \%$ of $\mathrm{CaO}$ in relation to in natura sugar cane. The result of the regression analysis showed a quadratic effect, with an estimated value of at least $110.0 \mathrm{~g} / \mathrm{kg}$ of hemicellulose for the level of $1.87 \%$ of $\mathrm{CaO}$ (Figure 2). The reduction in the values of the hemicellulose sugar cane to the level of $1.87 \% \mathrm{CaO}$ is related to the ability to hydrolyze lime and turn cell wall components soluble.

Table 3. Average levels in \% of dry matter, of neutral detergent fiber (NDF), acid detergent fiber (ADF), hemicellulose (HEM), cellulose, lignin, indigestible dry matter (iDM), indigestible neutral detergent fiber (iNDF) and in vitro digestibility of dry matter (IVDMD) of sugar cane in natura and treated with calcium oxide

\begin{tabular}{lccccccccc}
\hline \multirow{2}{*}{$\begin{array}{l}\text { Variables } \\
(\mathrm{g} / \mathrm{kg})\end{array}$} & $\begin{array}{c}\text { In Natura } \\
\text { Sugar Cane }\end{array}$ & 0 & 0,75 & 1,5 & 2,25 & 3,0 & 3,75 & 4,5 & CV \\
\cline { 3 - 8 } & Sug) & \\
\hline NDF & 501,0 & $579,0^{*}$ & $535,0^{*}$ & 481,0 & $426,0^{*}$ & $416,0^{*}$ & $419,0^{*}$ & $420,0^{*}$ & 2,5 \\
ADF & 385,0 & $430,0^{*}$ & $411,0^{*}$ & 369,0 & $318,0^{*}$ & $304,0^{*}$ & $289,0^{*}$ & $280,0^{*}$ & 4,0 \\
Hem & 116,0 & $148,0^{*}$ & 124,0 & 112,0 & 108,0 & 112,0 & 130,0 & $140,0^{*}$ & 9,9 \\
Cellulose & 310,0 & $349,0^{*}$ & $333,0^{*}$ & 301,0 & $264,0^{*}$ & $257,0^{*}$ & $247,0^{*}$ & $242,0^{*}$ & 4,3 \\
Lignin & 75,0 & 81,0 & 78,0 & $68,0^{*}$ & $54,0^{*}$ & $47,0^{*}$ & $42,0^{*}$ & $38,0^{*}$ & 6,5 \\
iDM & 235,0 & $255,0^{*}$ & 221,0 & $171,0^{*}$ & $135,0^{*}$ & $99,0^{*}$ & $87,0^{*}$ & $85,0^{*}$ & 5,3 \\
iFDN & 195,0 & 205,0 & 181,0 & $143,0^{*}$ & $111,0^{*}$ & $76,0^{*}$ & $70,0^{*}$ & $65,0^{*}$ & 6,4 \\
IVDMD & 56,1 & 55,5 & 56,0 & $59,8^{*}$ & $63,8^{*}$ & $66,2^{*}$ & $69,5^{*}$ & $72,7^{*}$ & 2,7 \\
\hline
\end{tabular}

* Means followed by an asterisk differ from in natura sugar cane (control) at $5 \%$ probability by Dunnett's test. $\mathrm{CV}=$ coefficient of variation in $\%, \mathrm{MN}=$ natural matter. ${ }^{1}(\% \mathrm{DM})$.

In this study the lignin was significantly reduced through the addition of 1.5 to $4.5 \% \mathrm{CaO}$ in sugar cane relative to in natura sugar cane (control) (Table 3). As can be seen in Table 3, there were significant differences $(\mathrm{P}<0.05)$ of lignin content with the addition of $\mathrm{CaO}$ levels to sugar cane, which represent a linear decrease (Figure 2).

Van Soest (1994) mentioned that during the alkali treatment, the lignin can be dissolved, which is in agreement with the observations made in this study. Checking for this component decreases the cell wall of sugar cane treated with $\mathrm{CaO}$. No effect of the $\mathrm{CaO}$ content on the lignin in forage is reported in literature. Balieiro Neto et al. (2007), evaluating the effects of $\mathrm{CaO}$ applied at the time of ensiling at levels of $0.5,1.0$ and $2.0 \%$ on the chemical composition of sugar cane silages during fermentation and postopening found no significant change in the lignin in 0.5 and $1.0 \% \mathrm{CaO}$, but found a reduction by $2.0 \%$ with the additive.

The results observed for lignin in this study differ from those found in some published literature on the subject. The lack of effect of $\mathrm{CaO}$ on lignin content of forage was verified in other studies such as those found by Carvalho et al. (2009), who when treating the crushed sugar cane with $\mathrm{CaO}(0,1.25,2.5$ and $3.75 \% \mathrm{DM}$ basis) for 12 and $36 \mathrm{~h}$ did not observe any influence of the levels of $\mathrm{CaO}$ and periods of no treatment in lignin content. Mota et al. (2010) obtained a similar result with the hydrolysis of sugar cane, lime or hydrated lime, where the lignin content showed no changes.

The fact that the effects observed in this study are relevant for evaluating the levels of lignin in comparison to $\mathrm{CaO}$ levels, and irrelevant to the aforementioned studies, can be linked to the initial composition of the material to be treated, including temperature and type of lime used, as well as the levels applied, since the experimental conditions differed between studies. Although few studies have tested the efficiency of $\mathrm{CaO}$, the information obtained in studies to this date indicates that this additive is showing results as satisfactory as other alkaline additives such as calcium hydroxide and urea appearing in the cell wall of forage sugar cane. Although Pires et al. (2006) has detected an elevated effect of alkaline hydrolysis of $\mathrm{NaOH}$ on cell wall components of sugar cane bagasse, causing a reduction of lignin with the inclusion of $0,2.5,5.0$ and $7.5 \% \mathrm{NaOH}$ (\% DM) and Carvalho et al. (2009) with the 
inclusion of $0,1.25,2.5$ and $3.75 \% \mathrm{CaO}(\%$ $\mathrm{DM})$, and have obtained the lignin 7.6, 5.9, 7.3 and $6.7 \%$ respectively, the results found in this study testing higher levels in relation to the study by Carvalho et al. (2009), proved more effective at levels of $0,0.75,1.5,2.25,3.0,3.75$ and $4.5 \%$ $\mathrm{CaO}$ with decreasing lignin, respectively, 81, 0 , $78.0, \quad 68.0, \quad 54.0, \quad 47.0, \quad 42.0$ and $38.0 \mathrm{~g} / \mathrm{kg}$ (Table 3).

The lignin in this study decreased with the addition of $1.5 \% \mathrm{CaO}$ to sugar cane in relation to in natura sugar cane obtaining similar results to those already found by Balieiro Neto et al. (2007), which showed that alkaline additives $(\mathrm{NaOH}$ or $\mathrm{CaO})$ also promote the partial reduction of lignin in testing the in natura sugar cane treated with $2.25 \% \mathrm{CaO}$ and treated with $2.25 \% \mathrm{NaOH}$ (\% DM). Lignin contents are 6.1, 1.3 and $0.9 \%$, corresponding to $61.0,13.0$ and $9 \mathrm{~g} / \mathrm{kg}$.

The average levels of indigestible dry matter (iDM) and indigestible neutral detergent fiber (iNDF), reduced $(\mathrm{P}<0.05)$ with increased levels of $\mathrm{CaO}$ in sugar cane (Figure 2). The behavior observed for iDM and iNDF joined linearly and negatively with the levels of $\mathrm{CaO}$ applied to sugar cane $(\mathrm{P}<0.05)$. The reduction of the levels of iDM and iNDF shows once again the action of $\mathrm{CaO}$ on the cell wall material, resulting in a decrease of indigestible fractions with increasing levels of $\mathrm{CaO}$. This behavior arises from the hydrolytic action of $\mathrm{CaO}$, causing a considerable change in the structure and composition of the cell wall, turning hemicelluloses partially soluble and allowing a greater utilization by the rumen microorganisms.

The IVDMD results were different between sugar cane and fresh sugar cane with $\mathrm{CaO}$ from the level of $1.5 \%$ (Table 2). The IVDMD increased $(\mathrm{P}<0.05)$ linearly as a function of $\mathrm{CaO}$ levels (Fig. 2). This result is explained by the alkaline hydrolysis of the fiber, resulting in a greater digestibility.

The results of this study corroborate results from the studies of Carvalho et al. (2009) that evaluated the chemical composition and IVDMD of hydrolyzed sugar cane bagasse with $\mathrm{CaO}$ in two treatment periods, founding IVDMD levels of $50.1,52.6,52.4$ and $55.4 \%$, respectively, for $0,1.25,2.5$ and $3.75 \%$ of $\mathrm{CaO}$. Carvalho et al.
(2006) increased levels of urea applied to sugar cane bagasse and sugar cane and also found a linear increase in IVDMD, with values of 33.0, $38.2,43.5$ and $48.8 \%$, respectively, for urea levels of $0,2.5,5.0$ and $7.5 \%$ (\% DM).

The linear increase of IVDMD based on the $\mathrm{CaO}$ levels found in this study is still in accordance with Balieiro Neto et al. (2007) who used the same additive at the time of ensiling at 0, 0.5, 1.0 and $2.0 \% \mathrm{CaO}$ levels with sugar cane, and observed an increase in IVDMD, with values of 62.1; 65.6, 70.7 and 79.2\% respectively. Cruz et al. (2009) also reported that the addition of $\mathrm{CaO}$ improved in vitro data with linear growth $(\mathrm{Y}=$ $3.8419 x+48.9427, \mathrm{R} 2=90.0)$, where every $1 \%$ of $\mathrm{CaO}$ added 3.8 points digestibility. The increase was also observed by IVDMD Cavali et al. (2010), which evaluated the effect of added $\mathrm{CaO}$ on the composition and ruminal degradability of dry matter and NDF, DM losses and silage microbial populations on sugarcane and increased IVDMD, with values of $66.9,70$, $2,71.4,73.4$ and $81.0 \%$ for $0,0.5,1.0,1.5$ and $2.0 \% \mathrm{CaO}$ in natura materials, and found a quadratic function by estimating the maximum $80.1 \%$ for the level of $1.8 \% \mathrm{CaO}$. Also using the same levels as Cavali et al. (2010), Rabelo et al. (2010) evaluated the chemobromatological composition and IVDMD of in natura sugar cane with $\mathrm{CaO}$ and observed no effect from the levels of $\mathrm{CaO}$ added to the average IVDMD of sugar cane $(56.49,57.58 ; 47.81$ and $52.78 \%)$.

\section{CONCLUSIONS}

Levels of calcium oxide starting at $1.5 \%$ in sugar cane improved the nutritional value and increased the in vitro digestibility of dry matter. Levels of calcium oxide starting at $0.75 \%$ increase the calcium content of sugar cane and should be taken into consideration in diet balancing in order to maintain the proper proportions of these minerals.

\section{REFERENCES}

ABRANCHES, J.L. e BOLONHEZI, A.C. Desenvolvimento inicial de variedades e clones de cana-de-açúcar em Latossolo Vermelho Distrófico, Aparecida do Taboado - MS. Rev. Bras. Cienc. Agrárias, v.6, p.369-375, 2011. 
AZEVEDO, J.A.G.; PEREIRA, J.C.; QUEIROZ, A.C. et al. Composição químico-bromatológica, fracionamento de carboidratos e cinética da degradação in vitro da fibra de três variedades de cana-de-açúcar (Saccharum spp.). Rev. Bras. Zootec., v.32, p.1443-1453, 2003.

BALIEIRO NETO, G.; SIQUEIRA, G.R.; REIS, R.A. et al. Óxido de cálcio como aditivo na ensilagem de cana-de-açúcar. Rev. Bras. Zootec., v.36, p.1231-1239, 2007.

BARBOSA, M.H.P.; SILVEIRA, L.C.I. Canade-açúcar: variedades, estabelecimento e manejo. In: SIMPÓSIO SOBRE MANEJO ESTRATÉGICO DA PASTAGEM, 3., 2006, Viçosa. Anais... Viçosa, 2006.

CARVALHO, G.G.P.; CAVALI, J.; FERNANDES, F.E.P. et al. Composição química e digestibilidade da matéria seca do bagaço de cana-de-açúcar tratado com óxido de cálcio. Arq. Bras. Med. Vet. Zootec., v.61, p.1346-1352, 2009.

CARVALHO, G.G.P.; GARCIA, R.; PIRES, A.J.V. et al. Diets Based on Sugar Cane Treated with Calcium Oxide for Lambs. Asian-Aust. J. Anim. Sci. v.26, p.218-226, 2013.

CARVALHO, G.G.P.; PIRES, A.J.V.; VELOSO, C.M. et al. Valor nutritivo do bagaço de cana-deaçúcar amonizado com quatro doses de ureia. Pesqu. Agropecuária Bras., v.41, p.125-132, 2006.

CASALI, A.O.; DETMANN, E.; VALADARES FILHO, S.C. et al. Influência do tempo de incubação e tamanho de partículas sobre os teores de compostos indigestíveis em alimentos e fezes bovinas obtidos por procedimento in situ. Rev. Bras. Zootec., v.37, p.335-342, 2008.

CAVALI, J.; PEREIRA, O.G.; VALADARES FILHO, S.C. et al. Bromatological and microbiolog. characteristics of sugarcane silages treated with calcium oxide. Rev. Bras. Zootec., v.39, p.1398-1408, 2010.

CRUZ, B.C.C.; SCHIO, A.R.; PIRES, A.J.V. et al. Parâmetros físico-químicos e fracionamento de carboidratos da cana-de-açúcar submetida a diferentes concentrações de óxido de cálcio. Publicações em Medicina Veterinária e Zootecnia (PUBVET), V.3, N.6, Ed. 67, Art. 307, 2009. Disponível em: http://www.pubvet.com.br/artigos_det.asp?artigo =307. Acessado em: 22/02/2012.
DUNNETT, C.W. A multiple comparison procedure for comparing several treatments with control. J. Am. State Associat., v.50, p.10961121, 1955.

FICK, K.R.; McDOWELL, L.R.; MILES, P.H. et al., Methods of mineral analysis for plant and animal tissues. 2th ed. University of Florida, Gainesville. 1979. 90p.

FISKE, C.H.; SUBBAROW, Y. The colorimetric determination of phosphorus. J. Biol. Chem., v.66, p.375-400, 1925.

FREITAS, A.W.P.; ROCHA, F.C.; ZONTA, A. Consumo de nutrientes e desempenho de ovinos alimentados com dietas à base de cana-de-açúcar hidrolisada. Pesquisa agropecuaria brasileira, v.43, p.1569-1574, 2008.

MERTENS, D.R. Gravimetric determination of amylase-treated neutral detergent fiber in feeds with refluxing in beaker or crucibles: collaborative study. J. AOAC Internat., v.85, p.1217-1240, 2002.

MOTA, D.A.; OLIVEIRA, M.D.S.; DOMINGUES, F.N. et al. Hidrólise da cana-de-açúcar com cal virgem ou cal hidratada. Rev. Bras. Zootec., v.39, p.1186-1190, 2010.

OLIVEIRA, M.D.S.; BARBOSA, J.C.; MOTA, D.A. et al. Efeito da hidrólise com cal virgem sobre a composição bromatológica da cana-deaçúcar. Vet. Notícias, v.14, p.19-27, 2008.

OLIVEIRA, A.S.; CAMPOS, J.M.S.; VALADARES FILHO, S.C. et al. Substituição do milho por casca de café ou de soja em dietas para vacas leiteiras: consumo, digestibilidade dos nutrientes, produção e composição do leite. Rev. Bras. Zootec., v.36, p.1172-1182, 2007.

OLIVEIRA, M.D.S.; QUEIROZ, M.A.A.; CALDEIRÃO, E. et al. Efeito da hidrólise com $\mathrm{NaOH}$ sobre a digestibilidade in vitro da matéria seca da cana-de-açúcar (Saccharum officinarum L.). Ars Vet., v.18, p.167-173, 2002.

PIRES, A.J.V.; CARVALHO, G.G.P.; RIBEIRO, L.S.O. Chemical treatment of roughage. Rev. Bras. Zootec., v.39 (supl. especial), p.192-203, 2010.

PIRES, A.J.V.; REIS, R.A.; CARVALHO, G.G.P. DE. et al. Bagaço de cana tratado com hidróxido de sódio. Rev. Bras. Zootec., v.35, p.953-957, 2006. 
RABELO, C.H.S.; REZENDE, A.V.; NOGUEIRA, D.A. et al. Composição químico-bromatológica e digestibilidade in vitro da matéria seca de canade-açúcar hidrolisada com cal virgem. Rev. Bras. Saúde Prod. Anim., v.11, p.1137-1149, 2010.

RIBEIRO, L.S.O.; PIRES, A.J.V.; CARVALHO, G.G.P. et al. Degradabilidade da matéria seca e da fração fibrosa da cana-de-açúcar tratada com hidróxido de sódio ou óxido de cálcio. Rev. Bras. Saúde Prod. Anim., v.10, p.573-585. 2009a.

RIBEIRO, L.S.O.; PIRES, A.J.V.; PINHO, B.D. et al. Valor nutritivo da cana-de-açúcar hidrolisada com hidróxido de sódio ou óxido de cálcio. Arq. Bras. Med. Vet. Zootec., v.61, p.1156-1164, 2009b.

SCHMIDT, P.; JUNIOR, P.R.; TOLEDO, L.M. et al. Perdas fermentativas e composição bromatológica da entrecasca de palmito pupunha ensilada com aditivos químicos. Rev. Bras. Zootec., v.39, p.262-267, 2010.

SNIFFEN, C.J; O'CONNOR, J.D.; van SOEST, P.J. et al. A net carbohydrate and protein system for evaluating cattle diets: II. Carbohydrate and protein availability. J. Anim. Sci., v.70, p.35623577, 1992.
SILVA, D.J.; QUEIROZ, A.C. Análise de alimentos: métodos químicos e biológicos. 3.ed. Viçosa: UFV, 2004. p.235.

SOBREIRA, G.F. Uso de cana-de-açúcar hidrolisada: alternativa para alimentação de ruminantes. Rev. Eletrônica Nutritime, v.3, p.318-321, 2006.

TILLEY, J.M.A.; TERRY, R.A. A two-stage technique for the in vitro digestion of forage crops. J. British Grassland Soc., v.18, p.104-111, 1963.

TOKARNIA C.H.; DÖBEREINER J.; PEIXOTO P.V. et al. Deficiências minerais em animais de fazenda, principalmente bovinos em regime de campo. Pesqu. Agrop. Bras., v.20, p.127-138, 2000.

Van SOEST, P.J. Nutritional ecology of the ruminant. 2nd ed. Ithaca: Cornell University Press, p.476, 1994.

Van SOEST, P.J.; ROBERTSON, J.B.; LEWIS, B.A. Methods for dietary fiber, neutral detergent fiber, and nonstarch polysaccharides in relation to animal nutrition. J. Dairy Sci., v.74, p.35833597, 1991. 